\title{
32. K-AR DATES FOR BASALTIC ROCKS FROM SITES 319 and 321, LEG 34
}

\author{
David E. Seidemann, Department of Geology and Geophysics, \\ Yale University, New Haven, Connecticut
}

\section{INTRODUCTION}

Whole rock K-Ar dates obtained for deep-sea basalts may be subject to inaccuracies for one or more of the following reasons:

1) Excess radiogenic $\mathrm{Ar}^{40}$ trapped in rapidly cooled submarine rocks at the time of their formation, leading to measured K-Ar dates older than the time of emplacement (Dalrymple and Moore, 1968).

2) Potassium addition at a time subsequent to the initiation of retention of $\mathrm{Ar}^{40}$ generated by in situ $\mathrm{K}^{40}$ decay in the rock, leading to measured $\mathrm{K}$-Ar dates younger than the time of emplacement.

3) $\mathrm{Ar}^{40}$ loss from labile sites found in altered basalts occurring either while the basalt is at the ocean bottom or since the time of recovery at room temperature and pressure. This leads to measured K-Ar dates younger than the time of emplacement.

The rocks analyzed from Leg 34 were probably free of excess radiogenic $\mathrm{Ar}^{40}$, but some and perhaps all the rocks have been affected by continuous $\mathrm{K}$ addition or by $\mathrm{Ar}^{40}$ loss from labile sites. Because the results reported in this study indicate that these effects definitely exist in some rocks, a complete reappraisal of the worth of whole rock K-Ar dates for deep-sea rocks is required.

\section{METHODS AND RESULTS}

Argon extraction was made using a conventional extraction system with an induction furnace. The argon isotopic composition was determined using a 6-inch radius, Nier-type mass spectrometer. $\mathrm{An} \mathrm{Ar}^{38}$ spike added before each analysis enabled calculation of the quantity of $\mathrm{Ar}^{40}$ released from the samples. Potassium analyses were made using standard atomic absorption techniques.

The results are presented in Table 1 together with a description of the samples.

\section{DISCUSSION}

\section{Hole 319}

A suite of basaltic rocks divided into at least six cooling units was encountered in Hole 319A. All of the Hole 319A samples dated were taken from the interiors of cooling units. The textures range from those of coarsegrained basalts to medium-grained diabases. Late quench textures are generally present. Studies of deepsea pillow basalts indicate that their interiors do not commonly contain excess $\mathrm{Ar}^{40}$, in spite of significant glass contents (Funkhouser et al., 1968; Dymond, 1970). Likewise, it is believed that these samples, because they were taken from the interiors of cooling units, probably do not contain excess $\mathrm{Ar}^{40}$, in spite of the presence of late quench textures.

Four of the samples dated were taken from the same cooling unit (the thickest encountered, estimated at 15.6 $\mathrm{m}$ thick) and ideally should have identical $\mathrm{K}-\mathrm{Ar}$ ages. Two of the samples from this unit (2-2, 109-109 cm; 3-2, 76-79 $\mathrm{cm}$ ) appeared altered (brownish) while the remaining two were relatively fresh (gray). The altered samples had higher $\mathrm{K}$ concentrations and lower ages $(\sim 0.3 \% \mathrm{~K}, 7$ m.y.) than the fresh samples $(\sim 0.1 \% \mathrm{~K}, 20 \mathrm{~m} . \mathrm{y}$.$) . The$ lower ages obtained for two of the samples from this unit are apparently due to the $\mathrm{K}$ addition to the samples, and not to later emplacement.

As reported in this volume, three environments of alteration can be distinguished in these rocks, the last of which was an oxidative one. It is believed that all three events occurred early, on or near the ridge crest, prior to the deposition of a sediment layer thick enough to impede diffusion of oxygen.

If the addition of $\mathrm{K}$ accompanied the early "oxidative" alteration of these rocks, then the low ages obtained must be related to $\mathrm{Ar}^{40}$ loss from labile sites. The $\mathrm{Ar}^{40}$ loss could occur either while the basalts are at the ocean bottom or perhaps after recovery at the increased temperature and greatly reduced pressure of the earth's surface.

On the other hand, $\mathrm{K}$ addition may not be contemporaneous with the early "oxidative" event, but may occur continuously. If so, the spatial association of alteration and high $\mathrm{K}$ contents must be explained. The spatial association may be the result of either (1) the early alteration of the rocks making these sites more susceptible to subsequent $\mathrm{K}$ fixation, or (2) the continuous formation of $\mathrm{K}$-rich minerals along the same channels that allowed the earlier entry of oxygen.

It is believed that the low $\mathrm{K}$ concentrations $(\sim 0.1 \% \mathrm{~K})$ found in the relatively fresh rocks better represent the original $\mathrm{K}$ concentrations of the rocks. The $\mathrm{K}-\mathrm{Ar}$ ages of approximately $20 \mathrm{~m} . \mathrm{y}$. obtained for the two fresh samples are believed to represent the best cooling age of this unit. This age is in good agreement with the 20-25 m.y. age for the crust at Site 319 as determined by the age-depth relationship suggested by Sclater et al. (1971).

The K-Ar age determined for the uppermost cooling unit in Hole 319A (Sample 1-1, 39-46 cm) is 7.1 \pm 2.2 m.y. The sample appears to be slightly altered and has a $\mathrm{K}$ content $40 \%$ greater than those found for the freshest samples in the thick cooling unit. This suggests that some $\mathrm{K}$ addition has occurred, lowering the age to some extent. The fact that the K-Ar age of the uppermost cooling unit is lower than that found for the thick unit may be entirely due to $\mathrm{K}$ addition, although it could also represent different emplacement times for the two units. 


\begin{tabular}{|c|c|c|c|c|c|c|c|c|c|}
\hline \multirow[b]{2}{*}{ Core } & \multicolumn{5}{|c|}{ Data } & \multicolumn{4}{|c|}{ Description } \\
\hline & Section & Interval & $\% \mathrm{~K}$ & $\begin{array}{c}\mathrm{Ar}^{40} \\
(\operatorname{ccs} \mathrm{STP} / \\
\left.\mathrm{gm} 10^{-6}\right)\end{array}$ & age(m.y.) & & $\begin{array}{l}\text { grain size } \\
\text { rock type }\end{array}$ & $\begin{array}{l}\text { color, state } \\
\text { of alteration }\end{array}$ & $\begin{array}{l}\text { expected age } \\
\text { and method }\end{array}$ \\
\hline \multicolumn{10}{|c|}{ Hole 319a } \\
\hline 1 & 1 & $39-46$ & 0.136 & 0.039 & $7.1 \pm 2.2$ & $\begin{array}{c}\text { probable } \\
\text { cooling } \\
\text { unit }\end{array}$ & $\begin{array}{c}\text { coarse-grained } \\
\text { basalt }\end{array}$ & $\begin{array}{l}\text { gray to yellow- } \\
\text { brown, slightly } \\
\text { altered }\end{array}$ & \multirow{5}{*}{$\begin{array}{l}20-25 \text { m.y. } \\
\text { Sclater et al. } \\
\text { age-depth } \\
\text { relationship }\end{array}$} \\
\hline 2 & 2 & $107-109$ & 0.270 & 0.084 & $7.8 \pm 2$ & \multirow{4}{*}{$\begin{array}{l}\text { probable } \\
\text { cooling } \\
\text { unit }\end{array}$} & $\begin{array}{c}\text { fine-grained } \\
\text { diabase }\end{array}$ & & \\
\hline 2 & 2 & $110-113$ & 0.095 & 0.075 & $19.8 \pm 3.6$ & & & gray, fresh & \\
\hline 3 & 2 & $76-79$ & 0.299 & 0.116 & $9.7 \pm 1.2$ & & & $\begin{array}{l}\text { yellow-brown, } \\
\text { altered }\end{array}$ & \\
\hline 3 & 3 & $84-87$ & 0.101 & 0.086 & $21 \pm 3$ & & $\begin{array}{c}\text { medium-grained } \\
\text { diabase }\end{array}$ & gray, fresh & \\
\hline \multicolumn{10}{|c|}{ Hole 321} \\
\hline $\int^{14}$ & 1 & $125-131$ & 0.183 & 0.168 & $22.8 \pm 1.4$ & & $\begin{array}{c}\text { fine-grained } \\
\text { basalt }{ }^{\mathrm{a}}\end{array}$ & $\begin{array}{l}\text { gray powder } \\
\text { from light } \\
\text { unaltered zone }\end{array}$ & $\begin{array}{l}38-40 \text { m.y. } \\
\text { Sclater et al. } \\
\text { age-depth } \\
\text { relationship }\end{array}$ \\
\hline$c_{14}$ & 1 & $125-131$ & 0.662 & 0.327 & $12.3 \pm 0.8$ & $\begin{array}{l}\text { cooling } \\
\text { unit }\end{array}$ & $\begin{array}{c}\text { fine-grained } \\
\text { basalt }^{\mathrm{a}}\end{array}$ & $\begin{array}{l}\text { yellow-brown } \\
\text { powder from dark } \\
\text { alteration zone }\end{array}$ & $\begin{array}{c}38-40 \text { m.y. } \\
\text { magnetic } \\
\text { anomaly }\end{array}$ \\
\hline 14 & 4 & $55-57$ & 0.108 & 0.121 & $27.8 \pm 3$ & & $\begin{array}{l}\text { fine-grained } \\
\text { basalt }\end{array}$ & gray, fresh & $\begin{array}{c}39-40 \mathrm{~m} . \mathrm{y} \\
\text { paleontologic } \\
\text { evidence }\end{array}$ \\
\hline
\end{tabular}

${ }^{\mathrm{a}}$ From same rock chip.

It should be noted that marked chemical differences exist between the two cooling units.

\section{Site 321}

The basaltic rocks encountered at Site 321 are probably from at least two cooling units. The dated samples are all from the thickest unit, which comprises all of Core 14 and the lower part of Core 13. Differences in ages cannot, therefore, be attributed to different emplacement times of different units. The basalt ranges in texture from very fine grained at the top of the unit to coarse grained at the bottom. The presence of finegrained basalt indicates fairly rapid cooling, but the abundance of vesicles suggests that the rock cooled sufficiently slowly to allow for evolution of a gas phase from the magma. Excess radiogenic $\mathrm{Ar}^{40}$ is therefore believed not to be present in the samples dated.

One of the Site 321 samples dated $(14-1,125-131 \mathrm{~cm})$ had veins of dark material adjacent to fissures. Areas not adjacent to the fissures were light. Powdered rock from dark areas had a browner color than powder from light areas. Both color and location indicate that the darker areas underwent alteration to a greater extent than the lighter areas. As in Hole 319A, the alteration was believed to have occurred early, prior to the deposition of a sediment layer thick enough to impede access of oxygenated waters. The dark material has a much higher $\mathrm{K}$ concentration and much lower age $(0.662 \% \mathrm{~K}$, $12.3 \pm 0.8$ m.y.) than those found for the light material $(0.183 \% \mathrm{~K}, 22.8 \pm 1.4 \mathrm{~m} . \mathrm{y}$.$) . The age difference within$ this single sample is certainly related to the difference in $\mathrm{K}$ content and not to a difference in emplacement time.
The $\mathrm{K}$ concentration of $0.183 \% \mathrm{~K}$ of the fresher of the Core 14, Section 1 samples is greater than that found for a sample of fresh, coarse-grained basalt (14-4, 55-57 $\mathrm{cm}: 0.108 \% \mathrm{~K}$ ) from deeper in the cooling unit. This may represent primary differences in $\mathrm{K}$ content. Alternatively, it may represennt $\mathrm{K}$ addition to the fresher of the two Core 14, Section 1 samples.

Therefore the measured $22.8 \pm 1.4 \mathrm{~m} . \mathrm{y}$. age may be lower than the age of the cooling unit. The age obtained for the fresher coarse-grained basalt $(14-4,55-57 \mathrm{~cm})$ is $27.8 \pm 3$ m.y.

Basaltic fragments and minerals found in the basal sediment suggest that the sediment-basalt contact is depositional. Thus, the paleontologic age determination, which implies 39-40 m.y. for the basal sediment, establishes a lower limit for the elapsed time since basalt emplacement. Magnetic anomaly patterns and the Sclater age-depth relationship indicate $38-40$ m.y. for the age of the crust in this area. The 38-40 m.y. age obtained using three different methods sheds doubt on the meaning of the $27.8 \pm 3$ m.y. K-Ar age obtained for the freshest Site 321 sample dated. One possible explanation for the discrepancy is that the $0.108 \% \mathrm{~K}$ found in the basalt, although low, has a significant component of $\mathrm{K}$ added to the basalt, lowering its age.

It is apparent from the data presented in this paper that conventional K-Ar whole rock ages for deep-sea basalts are not generally reliable because of the possibility of $\mathrm{K}$ addition to the basalts lowering their ages. It is recommended that mineral separation of high temperature phases (presumably retentive) and chemical etching be used in an attempt to eliminate the effects of 
$\mathrm{K}$ addition, perhaps allowing for determination of reliable $\mathrm{K}-\mathrm{Ar}$ ages for deep-sea basalts.

\section{ACKNOWLEDGMENTS}

This research was supported by National Science Foundation Grant GA 36673X. I thank Dr. K.K. Turekian for helpful discussion. Dr. M.N. Bass and Dr. S.R. Hart critically reviewed the manuscript.

\section{REFERENCES}

Dalrymple, G.B. and Moore, J.G., 1968. Argon 40: Excess in submarine pillow basalts from Kilauea Volcano, Hawaii: Science, v. 161, p. 1132-1135.

Dymond, J., 1970. Excess argon in submarine basalt pillows: Geol. Soc. Am. Bull., v. 81, p. 1229-1232.

Funkhouser, J.G., Fisher, E.E., and Bonatti, E., 1968. Excess argon in deep-sea rocks: Earth Planet. Sci. Lett., v. 5, p. 95-100.

Sclater, J.G., Anderson, R.N., and Bell, M.L., 1971. Elevation of ridges and evolution of the central East Pacific, J. Geophys. Res., v. 76, p. 7888-7915. 